\title{
A EDUCAÇÃO PARA ALÉM DO CAPITAL
}

\section{FILOMENO, Carlos Eduardo da Silva ${ }^{1}$}

O livro $A$ Educação para além do Capital (2a ed. São Paulo: Boitempo, 2008, 128p.), escrito por István Mészáros, foi produzido na forma de ensaio a partir da conferência de abertura do Fórum Mundial de Educação, realizado em julho de 2004, em Porto Alegre - RS. Neste ensaio, o professor emérito da Universidade de Sussex, Inglaterra, afirma que a educação não é um negócio, é criação. Enfatizando com veemência que "a educação não é mercadoria" e, portanto, esta não deve qualificar para o trabalho, mas para a vida. $O$ livro oferece a todos educadores e atores sociais envolvidos e empenhados com o processo educativo, uma rica lição sobre o real e essencial papel da educação.

Em A Educação para além do Capital, Mészáros alerta que é essencial buscar a superação da lógica desumanizadora do capital, que tem como colunas de sustentação o lucro, a competição e o individualismo. E defende a existência de práticas educacionais que possibilitem aos educadores e alunos trabalharem as mudanças necessárias para a construção de uma sociedade na qual o capital não explore o homem, pois as classes dominantes impõem uma educação para o trabalho alienante, a fim de manter o homem dominado. A obra apresenta uma reflexão acerca da possibilidade da superação da lógica do capital, por meio de processos educativos amplos, onde se anuncia a instauração de uma sociedade para além do capital, isto é, que transpasse o modelo vigente, que seja inovador.

Neste contexto, Mészáros pensa a educação na perspectiva de luta emancipatória onde é preciso construir uma ruptura com a lógica do capital. Assim, a educação não pode ser encerrada apenas no terreno da pedagogia, mas tem de sair às ruas, para os espaços públicos e se abrir para o mundo da forma mais ampla possível, pois somente deste modo, é possível sonhar com profundas transformações no sistema educacional.

Para embasar seus argumentos, recorre a Marx e Gramsci fazendo uma breve retrospectiva acerca das idéias que orientaram as políticas educacionais no capitalismo. 0 autor nos convida a entender o sistema de relações capital-trabalho, seus limites, suas contradições, seu movimento e seu horizonte de superação. Para tal, escolhe três epígrafes a fim de introduzir os principais pontos a serem abordados.

A primeira, do grande pensador do século XVI, Paracelso, em que dizia "A apren-

1 Pós graduando em Ensino de Ciências Lato sensus na UERJ. Email: duardo_rj@hotmail.com 
dizagem é a nossa própria vida, desde a juventude até a velhice, de fato quase até a morte; ninguém passa dez horas sem aprender"; a segunda, do político e revolucionário cubano José Martí, que insistia que "La educación empieza con la vida, y non acaba sino com la muerte". A contribuição da epígrafe de Martí vai além "Las redenciones han venido siendo formales; es necesario que sean esenciales [...] La libertad política no estará asegurada, mientras no se asegura la libertad espiritual. [...] La escuela y el hogar son las dos formidables cárceres del hombre". Por último, a terceira epígrafe escolhida pelo autor é retirada das Teses sobre Feuerbach de Marx, que diz "A teoria materialista de que os homens são produto das circunstâncias e da educação e que, portanto, homens modificados são produtos de circunstâncias diferentes e de educação modificada, esquece que as circunstâncias são modificadas precisamente pelos homens e que o próprio educador precisa ser educado. Leva, pois, forçosamente, à divisão da sociedade em duas partes, uma das quais se sobrepõe à sociedade (como, por exemplo, em Robert Owen). A coincidência da modificação das circunstâncias e da atividade humana só pode ser apreendida e racionalmente compreendida como prática transformadora".

A brilhante proposta de István Mészáros é destacar que não apenas a última citação, mas de alguma forma todas as três epígrafes, durante um período de mais de quatro séculos, enfatizam a urgência de se instituir uma mudança estrutural radical no modelo vigente. Uma mudança que nos leve para além do capital no sentido mais puro e educacionalmente viável do termo.

Parafraseando a epígrafe de José Martí, o autor afirma que "as soluções não podem ser apenas formais: elas devem ser essenciais". Contudo, no último século e ainda neste, a educação serviu não apenas para fornecer o conhecimento e o pessoal necessário à maquinaria produtiva em expansão do sistema capitalista, como também para gerar e transmitir valores que legitimam interesses dominantes de forma "internalizada" (indivíduos devidamente aceitos e educados, segundo a lógica do capital, verdadeiramente alienados e subordinados). Para Mészáros, as instituições formais de educação certamente são uma parte do sistema global de internalização, uma vez que os sujeitos são induzidos a uma aceitação ativa (ou um pouco resignada), dos princípios reprodutivos dominantes na própria sociedade, adequados a sua posição na ordem social.

O autor esclarece que a educação formal não é a força ideologicamente primária que consolida o sistema do capital; tampouco ela é capaz de, por si só, fornecer uma alternativa emancipatória radical, uma vez que uma das principais funções deste modelo educacional é produzir conformidade ou consenso, por meio de seus próprios limites institucionalizados e legalmente sancionados. Por este motivo, as soluções no âmbito educacional "não podem ser formais; elas devem ser essenciais", ou seja, devem abranger a plena totalidade das práticas educacionais da sociedade estabelecida.

A Educação para além do capital visa uma ordem social qualitativamente diferente, necessária e urgente, em resposta às incorrigíveis determinações da ordem atual, insustentável e alienante. A obra nos oferece uma tarefa educacional que promova uma 
transformação social ampla e emancipatória. Nenhuma posta à frente da outra. Assim, Mészáros propõe a construção de um pensamento educacional que combata a internalização e a consciência de subordinação dos valores mercantis, por meio de uma teoria e uma práxis educativa emancipadora e libertadora.

Todo educador deveria ler este livro para olhar a educação de uma forma crítica, perceber as relações que ela estabelece com o capital, quais as possibilidades de atuação no cenário sócio-educativo, além das amarras do modelo vigente. A necessidade de, neste momento, se pensar a educação para além do capital faz desse importante ensaio uma contribuição espetacular ao debate educacional, e mais que isso, é um chamado a outra forma de pensar e conceber o mundo através de uma educação que efetivamente atue para além do capital. 